\title{
Heat Capacity Changes Accompanying Micelle Formation upon Burial of Hydrophobic Tail of Nonionic Surfactants
}

\author{
Li-Jen Chen,* Yih-Heh Sheu, and Pei-Juian Li \\ Department of Chemical Engineering, National Taiwan University, Taipei, Taiwan 10617, Republic of China
}

Received: October 4, 2004; In Final Form: November 6, 2004

\begin{abstract}
The heat of micellization $\Delta H_{\mathrm{m}}$ for five nonionic surfactants $\left(\mathrm{C}_{10} \mathrm{E}_{5}, \mathrm{C}_{10} \mathrm{E}_{6}, \mathrm{C}_{10} \mathrm{E}_{7}, \mathrm{C}_{10} \mathrm{E}_{8}, \mathrm{C}_{8} \mathrm{E}_{5}\right)$ was measured as a function of temperature by using an isothermal titration calorimeter. The abbreviation $\mathrm{C}_{i} \mathrm{E}_{j}$ stands for the nonionic surfactant $\mathrm{CH}_{3}\left(\mathrm{CH}_{2}\right)_{i-1}\left(\mathrm{OCH}_{2} \mathrm{CH}_{2}\right)_{j} \mathrm{OH}$. The heat capacity change upon micellization $\Delta C_{p}$ was determined from $\Delta H_{\mathrm{m}}$ 's. It is found that $\Delta C_{p}$ is constant for four $\mathrm{C}_{10} \mathrm{E}_{j}$ 's. That is $\Delta C_{p}$ is independent of the chain length of hydrophilic headgroups. Furthermore, $\Delta C_{p}$ is directly proportional to the removal of water accessible nonpolar surface area $\Delta A_{\text {np. }}$. The ratio $\Delta C_{p} / \Delta A_{\text {np }}$ is equal to $-1.28 \pm 0.06 \mathrm{~J} \mathrm{~mol}^{-1} \mathrm{~K}^{-1} \AA^{-2}$ for $\mathrm{C}_{10} \mathrm{E}_{j}$ 's and $-1.34 \pm 0.06 \mathrm{~J} \mathrm{~mol}^{-1} \mathrm{~K}^{-1} \AA^{-2}$ for $\mathrm{C}_{8} \mathrm{E}_{5}$, consistent with that observed upon protein folding $\left(-1.34 \pm 0.33 \mathrm{~J} \mathrm{~mol}^{-1} \mathrm{~K}^{-1} \AA^{-2}\right.$ ) of Spolar et al. (Biochemistry 1992, 31, 3947.).
\end{abstract}

When surfactant molecules are dissolved in water up to a certain concentration, known as critical micelle concentration, they can achieve segregation of their hydrophobic portions from water to form micelles. The hydrophobic effect due to the interaction between the hydrocarbon tail of the surfactant and water plays an important role in micelle formation. ${ }^{1-8}$ According to the working scheme of Lumry and Rajender, ${ }^{9}$ the micellization can be described as consisting of two part processes: the dehydration of the hydrocarbon tail of surfactant molecules and the aggregation of the hydrocarbon tails of surfactant molecules to form a micelle. In addition, the self-organization of surfactants into membranes, protein folding, and nonpolar gas solubility are just a few examples of processes also governed by the hydrophobic interaction. ${ }^{10-12}$

It is well believed that the hydrophobic interaction is a dominant factor that stabilizes the native protein structure. Thermodynamic parameters that describe the hydrophobic interaction of different protein groups with water have been the subject of numerous experimental and theoretical studies. ${ }^{13-19}$ Baldwin ${ }^{13}$ proposed that the heat capacity change of protein folding could be applied to quantify the contribution of the hydrophobic interaction to the stability of a globular protein. The protein folding process is always accompanied by a large negative heat capacity change. ${ }^{14,16}$ The heat capacity change upon protein folding displays a feature similar to those characteristic of pure hydrocarbons as well as surfactants in water, as has been recognized for a long time..$^{20}$ Therefore, the heat capacity changes upon protein folding are mainly due to the nonpolar groups of the protein that are buried in the native state and become water exposed in the unfolded state. It was found that the change of heat capacity is directly proportional to the change of water accessible nonpolar surface area upon transferring a hydrocarbon compound to water. Record and coworkers ${ }^{21}$ proposed that this proportionality can be straightforwardly applied to extrapolate the experimental thermodynamic data on the heat capacity changes of protein folding. However, in the native protein structure, not only nonpolar but also polar groups are buried upon protein folding. ${ }^{22,23}$ Thus the burial of

* Correesponding author. E-mail: ljchen@ntu.edu.tw. the polar groups from water upon protein folding should also contribute to the heat capacity changes. The heat capacity change upon the decrease of water accessible polar surface area should have a positive heat capacity change, that is, a sign opposite to that of the decrease of water accessible nonpolar surface area. Spolar et al. (1992) ${ }^{23}$ concluded an equation to estimate the heat capacity change of protein folding $\Delta C_{p}$ from the changes of water accessible nonpolar and polar surface areas.

$$
\begin{aligned}
\Delta C_{p}\left(\mathrm{~J} \mathrm{~mol}^{-1} \mathrm{~K}^{-1}\right)=-1.34( \pm 0.33) \Delta A_{\mathrm{np}}\left(\AA^{2}\right)+ \\
0.59( \pm 0.17) \Delta A_{\mathrm{p}}\left(\AA^{2}\right)
\end{aligned}
$$

where $\Delta A_{\text {np }}$ and $\Delta A_{\mathrm{p}}$ stand for the removal of water accessible nonpolar and polar, respectively, surface area upon protein folding.

Consider the heat capacity change upon micellization of surfactant $\mathrm{C}_{i} \mathrm{E}_{j}$ 's. The heat capacity change $\Delta C_{p}$ can be empirically related to changes in hydrophobic and hydrophilic solvation upon protein folding, as shown in eq 1 . Because the hydrophilic headgroups of nonionic surfactants remain hydrated upon micelle formation, $\Delta C_{p}$ can be assumed to solely reflect the change in the exposure of hydrophobic tails to water. If the chain length of the hydrophobic tail is fixed, then the heat capacity change in micellization $\Delta C_{p}$ should be constant and independent of the chain length of the hydrophilic headgroup. The purpose of this study is to provide experimental data to verify this point. In addition, the validity of eq 1 is also examined upon the micellization process.

Nonionic surfactants $\mathrm{C}_{10} \mathrm{E}_{5}, \mathrm{C}_{10} \mathrm{E}_{6}, \mathrm{C}_{10} \mathrm{E}_{7}$, and $\mathrm{C}_{10} \mathrm{E}_{8}$ were purchased from Nikko Chemicals Co. and $\mathrm{C}_{8} \mathrm{E}_{5}$ from Bachem AG. All these surfactants were used as received without further purification. The abbreviation $\mathrm{C}_{i} \mathrm{E}_{j}$ stands for the nonionic surfactant $\mathrm{CH}_{3}\left(\mathrm{CH}_{2}\right)_{i-1}\left(\mathrm{OCH}_{2} \mathrm{CH}_{2}\right)_{j} \mathrm{OH}$. Water was purified by a Milli-RO plus (Millipore) and Milli-Q (Millipore) in series with the resistance better than $18 \mathrm{Mohm}-\mathrm{cm}$.

The isothermal titration calorimeter of Thermometric (TAM 2277) was applied to perform the heat of mixing. In an experiment, $3 \mathrm{~g}$ of water was filled in a $4 \mathrm{~mL}$ stainless steel ampule. The injection syringe (Hamilton) was filled with a concentrated solution of a surfactant, which was injected 5-15 

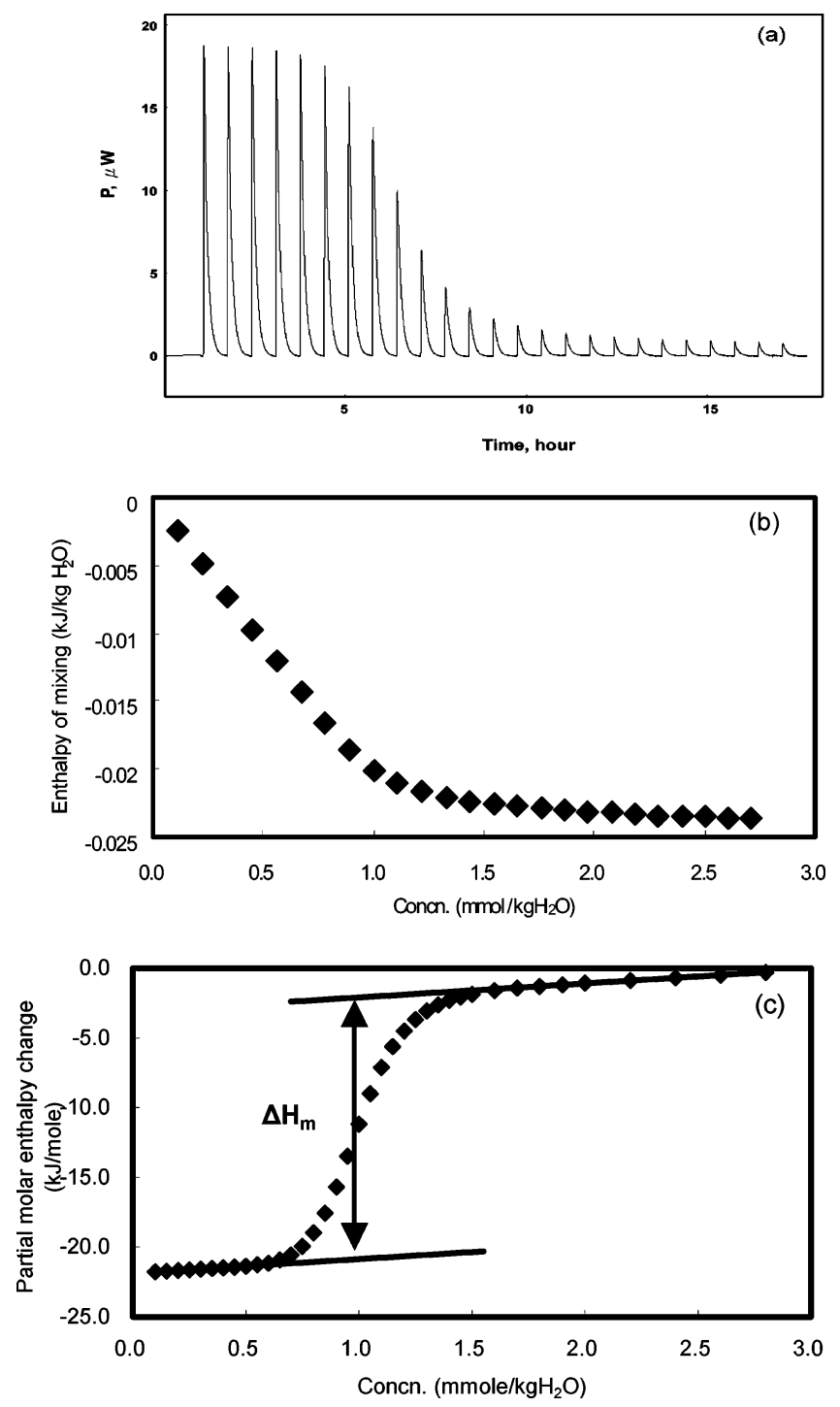

Figure 1. (a) A typical thermogram of titration curve (heat flow vs time). (b) Heat of mixing as a function of molality. (c) Partial molar enthalpy of $\mathrm{C}_{10} \mathrm{E}_{\mathrm{j}}$ as a function of molality.

$\mu \mathrm{L}$ in each titration into the pure water (or solution) in the ampule by using a computer-controlled syringe pump (Lund, Sweden) at 45 min intervals under constant stirring condition at a prescribed temperature. The heat flows through highly sensitive thermopiles surrounded by a heat sink, stabilized within $\pm 2 \times 10^{-4}{ }^{\circ} \mathrm{C}$, were recorded. The weight of injected solution was evaluated from the density of the concentrated surfactant solution, which was measured by using a vibrating-tube densiometer (Paar DAM 58, Austria). The experiments were performed in at least three individual runs at a given temperature. The determination of the heat of micellization $\Delta H_{\mathrm{m}}$ closely followed the method proposed by Paula et al. (1995). ${ }^{24}$ Figure 1a shows a typical experimental titration thermogram from consecutively injecting concentrated $\mathrm{C}_{10} \mathrm{E}_{j}$ solution into the ampule at $298.15 \mathrm{~K}$. The heat of mixing for each titration was determined by its peak area. The heat of mixing at a given surfactant concentration was evaluated by summing up the area from the first peak to the one of the prescribed concentration. Figure 1b illustrates the heat of mixing vs the surfactant concentration in the ampule. The derivative of the heat of mixing with respect to the surfactant concentration yields the partial molar enthalpy change of $\mathrm{C}_{10} \mathrm{E}_{j},{ }^{4}$ as shown in Figure 1c. The experimental data in Figure 1c were then correlated by a
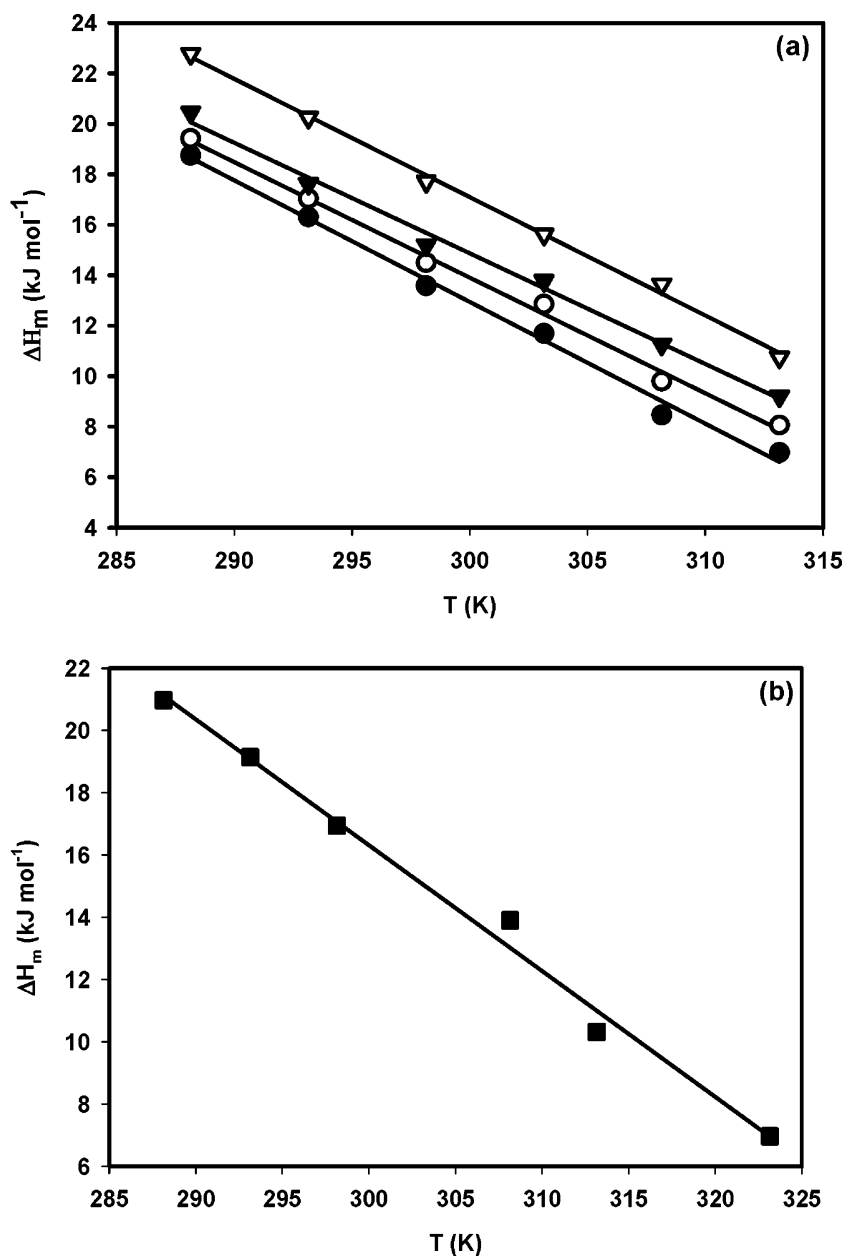

Figure 2. The experimental results of the heat of micellization as a function of temperature. (a) $\mathrm{C}_{10} \mathrm{E}_{5}(\bullet), \mathrm{C}_{10} \mathrm{E}_{6}(\mathrm{O}), \mathrm{C}_{10} \mathrm{E}_{7}(\boldsymbol{\nabla})$ and $\mathrm{C}_{10} \mathrm{E}_{8}$ $(\nabla)$; (b) $\mathrm{C}_{8} \mathrm{E}_{5}(\mathbf{\square})$.

sigmoidal curve. The inflection point of this sigmoidal curve gives the critical micelle concentration $(\mathrm{cmc})$. The heat of micellization $\Delta H_{\mathrm{m}}$ is equal to the enthalpy difference between two extrapolated lines right at $\mathrm{cmc}$, as illustrated in Figure 1c. Replicate measurements of $\Delta H_{\mathrm{m}}$ indicated a precision of less than $5 \%$ deviation.

The experimental results of the heat of micellization $\Delta H_{\mathrm{m}}$ as a function of temperature are illustrated in Figure 2a for four nonionic surfactants: $\mathrm{C}_{10} \mathrm{E}_{5}, \mathrm{C}_{10} \mathrm{E}_{6}, \mathrm{C}_{10} \mathrm{E}_{7}$, and $\mathrm{C}_{10} \mathrm{E}_{8}$, and Figure $2 \mathrm{~b}$ for $\mathrm{C}_{8} \mathrm{E}_{5}$. On average, $\Delta H_{\mathrm{m}}$ increases by $1.28 \pm 0.03 \mathrm{~kJ}$ $\mathrm{mol}^{-1}$ when the hydrophilic headgroup increases by one oxyethylene group. This enthalpy difference per oxyethylene group is simply due to the interactions between the hydrophilic headgroups stretching out of the core (formed by the hydrophobic tails) of micelles. The increase of hydrophilic chain length would certainly enhance the interactions between the hydrophilic chains.

Linear regression was applied to describe the temperature dependence of $\Delta H_{\mathrm{m}}$ for each surfactant, and the slope of each line, shown in Figure 2, gives the heat capacity change upon micellization $\Delta C_{p}$. The values of $\Delta C_{p}$ 's for four surfactants $\mathrm{C}_{10} \mathrm{E}_{5}, \mathrm{C}_{10} \mathrm{E}_{6}, \mathrm{C}_{10} \mathrm{E}_{7}$, and $\mathrm{C}_{10} \mathrm{E}_{8}$ were found out to be $-0.48 \pm$ $0.02,-0.46 \pm 0.02,-0.44 \pm 0.02$, and $-0.47 \pm 0.01 \mathrm{~kJ} \mathrm{~mol}^{-1}$ $\mathrm{K}^{-1}$, respectively. Indeed, it is found that all four surfactants of the same hydrophobic chain length but with different hydrophilic chain lengths $\left(\mathrm{C}_{10} \mathrm{E}_{j}\right.$ and $\left.j=5-8\right)$ have a constant $\Delta C_{p}$, as expected. This confirms our conjecture that the heat capacity change $\Delta C_{p}$ is constant for four $\mathrm{C}_{10} \mathrm{E}_{j}$ surfactants. The 
average value of $\Delta C_{p}$ for these four $\mathrm{C}_{10} \mathrm{E}_{j}$ surfactants is -0.46 $\pm 0.02 \mathrm{~kJ} \mathrm{~mol}^{-1} \mathrm{~K}^{-1}$. Note that $\Delta C_{p}$ of micellization is solely attributed to the change in the exposure of hydrophobic tails to water, and independent of the hydrophilic chain length. Although for $\mathrm{C}_{8} \mathrm{E}_{5}, \Delta C_{p}=-0.40 \pm 0.02 \mathrm{~kJ} \mathrm{~mol}^{-1} \mathrm{~K}^{-1}$, the heat capacity change per methylene upon micellization can be estimated to be $-40 \pm 20 \mathrm{~J} \mathrm{~mol}^{-1} \mathrm{~K}^{-1}$ from $\Delta C_{p}$ 's of $\mathrm{C}_{8} \mathrm{E}_{5}$ and $\mathrm{C}_{10} \mathrm{E}_{5}$. That is close to, at least within experimental uncertainty of, the literature value for the heat capacity change per methylene for transferring of an alkyl chain from an aqueous to a hydrocarbon environment $-49.2 \mathrm{~J} \mathrm{~mol}^{-1} \mathrm{~K}^{-1}$.

A more crucial examination is to check the validity of eq 1 to the micellization process. There is no removal of water accessible polar surface area upon micelle formation, because the hydrophilic headgroups of $\mathrm{C}_{i} \mathrm{E}_{j}$ surfactants remain hydrated. That is, $\Delta A_{\mathrm{p}}=0$. Richards and co-workers ${ }^{25}$ developed an algorithm to estimate the water accessible surface area of a protein. According to Richards, ${ }^{26}$ the water accessible surface areas of one methylene group $\left(-\mathrm{CH}_{2}-\right)$ and of one methyl group $\left(-\mathrm{CH}_{3}\right)$ are 30 and $88 \AA^{2}$, respectively. The hydrophobic tail of a surfactant $\mathrm{C}_{10} \mathrm{E}_{j}$ is composed of nine methylene groups and one methyl group. Thus, the water accessible surface area of the hydrophobic tail of a surfactant $\mathrm{C}_{10} \mathrm{E}_{\mathrm{j}}$ molecule is 358 $\AA^{2}(=9 \times 30+88)$, and that of $\mathrm{C}_{8} \mathrm{E}_{5}$ is $298 \AA^{2}$. For micelle formation of a surfactant $\mathrm{C}_{i} \mathrm{E}_{j}$, the whole hydrophobic tail is assumed to bury inside to form the core of a micelle. That is, for micelle formation, $\Delta A_{\mathrm{np}}=358 \AA^{2}$ for $\mathrm{C}_{10} \mathrm{E}_{j}$ and $\Delta A_{\mathrm{np}}=$ $298 \AA^{2}$ for $\mathrm{C}_{8} \mathrm{E}_{5}$. Furthermore, the ratio of $\Delta C_{p}$ and $\Delta A_{\mathrm{np}}$ for micellization was calculated, $\Delta C_{p} / \Delta A_{\mathrm{np}}=-1.28 \pm 0.06 \mathrm{~J} \mathrm{~mol}^{-1}$ $\mathrm{K}^{-1} \AA^{-2}$ for $\mathrm{C}_{10} \mathrm{E}_{j}$ and $-1.34 \pm 0.06 \mathrm{~J} \mathrm{~mol}^{-1} \mathrm{~K}^{-1} \AA^{-2}$ for $\mathrm{C}_{8} \mathrm{E}_{5}$, that is in excellent agreement with the value $-1.34 \pm 0.17 \mathrm{~J}$ $\mathrm{mol}^{-1} \mathrm{~K}^{-1} \AA^{-2}$ deduced from protein folding, appearing in eq $1 .^{23}$ That is, eq 1 is still valid to the heat capacity change for nonionic surfactants.

In conclusion, we present here the first experimental evidence that the anomalous heat capacity change upon micellization for a nonionic surfactant $C_{i} E_{j}$ is mainly due to the hydrophobic interaction of the hydrophobic tail solely. In addition, there is no contribution to the heat capacity change from the hydrophilic headgroup. It is much more interesting to demonstrate that the heat capacity change upon micellization is directly proportional to the removal of water accessible nonpolar surface area, as described by eq 1 , that is a relationship deduced from protein folding. Currently, we are in the process of further verifying the validity of eq 1 to other types of surfactants.

Acknowledgment. This work was supported by the National Science Council of Taiwan.

\section{References and Notes}

(1) Tanford, C. The Hydrophobic Effect; 2nd ed.; John-Wiley: New York, 1980 .
(2) Kresheck, G. C. In Water: A Comprehensive Treatise; Franks, F. Ed.; Plenum Press: New York, 1975; Vol. 4, Chapter 2.

(3) (a) Gill, S. J.; Wadsö, I. Proc. Natl. Acad. Sci. U.S.A. 1976, 73, 2955. (b) Gill, S. J.; Nichols, N. F.; Wadsö, I. J. Chem. Thermodyn. 1976, $8,445$.

(4) (a) Aratono, M.; Ohta, A.; Ikeda, N.; Matsubara, A.; Motomura, K.; Takiue, T. J. Phys. Chem. B 1997, 101, 3535. (b) Ohta, A.; Murakami, R.; Takiue, T.; Ikeda, N.; Aratono, M. J. Phys. Chem. B 2000, 104, 8592. (5) (a) Chen, L.-J.; Lin, S.-Y.; Huang, C.-C. J. Phys. Chem. B 1998, 102, 4350. (b) Chen, L.-J.; Lin, S.-Y.; Huang, C.-C.; Chen, E.-M. Colloid Surf. A 1998, 135, 175 .

(6) (a) Kresheck, G. C. J. Am. Chem. Soc. 1998, 120, 10964. (b) Kresheck, G. C. J. Phys. Chem. B 1998, 102, 6596.

(7) (a) Sugihara, G.; Hisatomi, M. J. Colloid Interface Sci. 1999, 219, 31. (b) Okano, T.; Tamura, T.; Nakano, T.-Y.; Ueda, S.-I.; Lee, S.; Sugihara, G. Langmuir 2000, 16, 3777. (c) Hisatomi, M.; Abe, M.; Yoshino, N.; Lee, S.; Nagadome, S.; Sugihara, G. Langmuir 2000, 16, 1515.

(8) Moroi, Y. Micelles; Plenum Press: New York and London, 1992.

(9) Lumry, R.; Rajender, S. Biopolymers 1970, 9, 1125.

(10) Hammett, L. P. Physical Organic Chemistry: Reaction Rates, Equilibrium, and Mechanism, 2nd ed.; MaGraw-Hill: New York, 1970.

(11) Lumry, R.; Gregory, R. B. In The Fluctuating Enzyme; Welch, G. R., Ed.; Wiley: New York, 1986; pp 1-190.

(12) Lumry, R. In Methods in Enzymology; Ackers, G. K.; Johnson, M. L., Eds.; Academic: New York, 1995; Vol. 259, pp 628-720.

(13) (a) Baldwin, R. L. Proc. Natl. Acad. Sci. U.S.A. 1986, 83, 8069 (b) Baldwin, R. L.; Muller, N. Proc. Natl. Acad. Sci. U.S.A. 1992, 89, 7110 (14) Kauzmann, W. Adv. Protein Chem. 1959, 14, 1

(15) (a) Dill, K. A. Biochemistry 1990, 29, 7133. (b) Silverstein, K. A. T.; Haymet, A. D. J.; Dill, K. A. J. Am. Chem. Soc. 1998, 120, 3166. (c) Southall, N. T.; Dill, K. A. J. Phys. Chem. B 2000, 104, 1326. (d) Urbič, T.; Vlachy, V.; Kalyuzhnyi, Y. K.; Southall, N. T.; Dill, K. A. J. Chem. Phys. 2002, 116, 723 .

(16) (a) Privalov, P. L. Adv. Protein Chem. 1979, 33, 167. (b) Privalov, P. L.; Gill, S. J. Adv. Protein Chem. 1988, 39, 191.

(17) (a) Lum, K.; Chandler, D.; Weeks, J. D. J. Phys. Chem. B 1999, 103, 4570. (b) Chandler, D. Science 2002, 417, 491. (c) Gallagher, K. R.; Sharp, K. P. J. Am. Chem. Soc. 2003, 125, 9853. (d) Sharp, K. Protein Sci. 2001, 10, 661. (e) Sharp, K. A.; Madan, B. J. Phys. Chem. B 1997, 101, 4343. (f) Widom, B.; Bhimalapuram, P.; Koga, K. Phys. Chem. Chem. Phys. 2003, 5, 3085. (g) Maibaum, L.; Dinner, A. R.; Chandler, D. J. Phys. Chem. B 2004, 108, 6778. (h) Huang, D. M.; Chandler, D. Proc. Natl. Acad. Sci. U.S.A. 2000, 97, 8324.

(18) (a) Murphy, K.; Freire, E. Adv. Protein Chem. 1992, 43, 313. (b) Fu, L.; Freire, E. Proc. Natl. Acad. Sci. U.S.A. 1992, 89, 9335. (c) Murphy, K. P.; Privalov, P. L.; Gill, S. J. Science 1990, 247, 559.

(19) (a) Sturtevant, J. M. Proc. Natl. Acad. Sci. U.S.A. 1977, 74, 2236.

(b) Velicelebi, G.; Sturtevant, J. M. Biochemistry 1979, 18, 1180.

(20) (a) Edsall, J. T. J. Am. Chem. Soc. 1935, 57, 1506. (b) Wilhelm, E.; Battino, R.; Wilcock, R. J. Chem. Rev. 1977, 77, 219.

(21) (a) Spolar, R. S.; Ha, J.-H.; Record, M. T., Jr. Proc. Natl. Acad. Sci. U.S.A. 1989, 86, 8382. (b) Livingstone, J. R.; Spolar, R. S.; Record, M. T., Jr. Biochemistry 1991, 30, 4237.

(22) (a) Loladze, V. V.; Ermolenko, D.; Makhatadze, G. I. Protein Sci. 2001, 10, 1343. (b) Ooi, T.; Oobatake, M.; Nemethy, G.; Scheraga, H. A. Proc. Natl. Acad. Sci. U.S.A. 1987, 84, 3086. (c) Bergqvist, S.; Williams, M. A.; O'Brien, R.; Ladbury, J. E. J. Mol. Biol. 2004, 336, 829.

(23) Spolar, R. S.; Livingstone, J. R.; Record, M. T., Jr. Biochemistry $1992,31,3947$.

(24) (a) Paula, S.; Süs, W.; Tuchtenhagen, J.; Blume, A. J. Phys. Chem. 1995, 99, 11742. (b) Heerklotz, H.; Epand, R. M. Biophys. J. 2001, 80 , 271.

(25) Lee, B.; Richards, F. M.J. Mol. Biol. 1971, 55, 379.

(26) (a) Richards, F. M. J. Mol. Biol. 1974, 82, 1. (b) Richards, F. M. Annu. Rev. Biophys. Bioeng. 1977, 6, 151. (c) Richards, F. M. Methods Enzymol. 1985, 115, 440. 